Pesq. Vet. Bras. 30(4):363-372, abril 2010

\title{
Establishment of a protocol for obtention of neuronal stem cells lineages from the dog olfactory epithelium ${ }^{1}$
}

\author{
Flávio R. Alves ${ }^{2 \star}$, Ricardo R. Guerra ${ }^{3}$, Emerson T. Fioretto ${ }^{4}$, Juliana C. Delgado ${ }^{5}$, \\ Antônio A. N. Machado Júnior ${ }^{2}$, Carlos E. Ambrósio ${ }^{7}$, I. Kerkis ${ }^{6}$ and Maria A. Miglino
}

ABSTRACT.- Alves F.R., Emerson T.F., Ricardo R.G., Juliana C.D., Antônio A.N.M.J., Ambrósio C.E., Irina K. \& Miglino M.A. 2010. Establishment of a protocol for obtention of neuronal stem cells lineages from the dog olfactory epithelium. Pesquisa Veterinária Brasileira 30(4):363-372. Departamento de Ciência Animal, Campus Universitário, Bairro Cibrazen, Bom Jesus, PI 64900-000, Brazil. E-mail: flavioribeiro@ufpi.edu.br

A morphological and cell culture study from nasal mucosa of dogs was performed in order to establish a protocol to obtain a cell population committed to neuronal lineage, as a proposal for the treatment of traumatic and degenerative lesions in these animals, so that in the future these results could be applied to the human species. Twelve mongrel dogs of 60-day aged pregnancy were collected from urban pound dogs in São Paulo. Tissue from cribriform ethmoidal lamina of the fetuses was collected at necropsy under sterile conditions around $1 \mathrm{~h}$ to $2 \mathrm{~h}$ postmortem by uterine sections and sections from the fetal regions described above. Isolated cells of this tissue were added in DMEM/F-12 medium under standard conditions of incubation $\left(5 \% \mathrm{CO}^{2},>37^{\circ} \mathrm{C}\right)$. Cell culture based on isolated cells from biopsies of the olfactory epithelium showed rapid growth when cultured for 24 hours, showing phase-bright sphere cells found floating around the fragments, attached on culture flasks. After 20 days, a specific type of cells, predominantly ellipsoids or fusiform cells was characterized in vitro. The indirect immunofluorescence examination showed cells expressing markers of neuronal precursors (GFAP, neurofilament, oligodendrocyte, and III â-tubulin). The cell proliferation index showed Ki67 immunostaining with a trend to label cell groups throughout the apical region, while PCNA immunostaining label predominantly cell groups lying above the basal lamina. The transmission electron microscopy from the olfactory epithelium of dogs revealed cells with electron-dense cytoplasm and preserving the same distribution as those of positive cell staining for PCNA. Metabolic activity was confirmed by presence of euchromatin in the greatest part of cells. All these aspects give subsidies to support the hypothesis about resident progenitor cells among the basal cells of the olfactory epithelium, committed to renewal of these cell populations, especially neurons.

INDEX TERMS: Olfactory epithelium, canine cell culture, animal stem cell.

\footnotetext{
${ }^{1}$ Received on August 24, 2009.

Accepted for publication on December 20, 2009.

2 Disciplina Diagnóstico por Imagem, Curso de Medicina Veterinária, Universidade Federal do Piauí (UFPI), Campus Cinobelina Elvas, BR $125 \mathrm{Km} 3$, Planalto Cibrazem, Bom Jesus, PI 64900-000, Brazil. *Autor para correspondência: flavioribeiro@ufpi.edu.br

${ }^{3}$ Departamento de Ciências Veterinárias, Centro de Ciências Agrárias, Universidade Federal da Paraíba, Campus III, Areia, PB 58397000 , Brazil

${ }^{4}$ Laboratório de Biologia Celular e Estrutural, Departamento de Morfologia, Centro de Ciências Biológicas e da Saúde, Universidade Fede-
}

ral de Sergipe, Av. Marechal Rondon s/n, São Cristovão, SE 49100000, Brazil.

${ }^{5}$ Departamento de Cirurgia, Faculdade de Medicina Veterinária e Zootecnia (FMVZ), Universidade de São Paulo, Av. Prof. Dr. Orlando Marques de Paiva 87, Cidade Universitária, São Paulo, SP 05508-270, Brazil.

${ }^{6}$ Laboratório de Genética, Instituto Butantan, Av. Vital Brasil 1500, Butantan, São Paulo, SP 05503-900.

${ }^{7}$ Departamento de Ciências Básicas, Faculdade de Zootecnia e Engenharia de Alimentos (FZEA), Universidade de São Paulo, Av. Duque de Caxias Norte 225, Campus da USP, Pirassununga, SP 13635-270. 
RESUMO.- [Estabelecimento de um protocolo para obtenção de linhagens de células-tronco neuronais a partir do epitélio olfatório de cães.] Foi realizado um estudo morfológico e por cultivo celular a partir de células provenientes da mucosa olfatória de cães, como forma de estabelecer um protocolo de cultivo, como uma proposta para o tratamento de lesões traumáticas e nervosas degenerativas nestes animais e futuramente, para que tais resultados possam ser aplicados a espécie humana. Foram utilizados doze cães sem raça definida, a termo, oriundos de castrações do Centro de Controle de Zoonoses de São Paulo. O tecido da lâmina cribiforme do etmóide dos fetos foi coletado sob necropsia, em condições estéreis, 1 a 2 horas post mortem, por meio de incisão uterina e acesso da região fetal supracitada. Depois as células isoladas desse tecido foram adicionadas em médio DMEM/F-12 sob condições padrão $\left(5 \% \mathrm{CO}^{2},>37^{\circ} \mathrm{C}\right)$. As células obtidas a partir de biópsias do epitélio olfatório de cães apresentaram rápido crescimento após 24 horas de cultivo, demonstrando morfologia esférica, sendo encontradas flutuando ao redor do fragmento aderido à garrafa de cultura. Após 20 dias, foram verificados tipos celulares específicos, predominantemente elipsóides ou fusiformes, foram observadas in vitro. Sob avaliação por imunofluorescência indireta observaram-se células com expressão positiva para marcadores de precursores neuronais (GFAP, Neurofilamentos, oligodendrócitos e â-tubulina III). $O$ índice de proliferação celular mostrou-se positivo para Ki67 com uma tendência de marcação de grupos celulares ao longo da região apical, enquanto a imunomarcação para PCNA mostrou-se predominantemente em grupos celulares residentes sobre a lâmina basal. A microscopia eletrônica de transmissão do epitélio olfatório de cães revelou células com citoplasma eletrodenso e mesma distribuição das células marcadas positivamente para PCNA. A atividade metabólica foi confirmada pela presença de eucromatina em muitas regiões celulares. Todos estes aspectos sustentam a hipotese sobre a presença de células progenitoras residentes entre as células basais do epitélio olfatório comprometidas com a renovação desse epitélio, particularmente a população de neurônios.

TERMOS DE INDEXAÇÃO: Epitélio olfatório, cultivo de células caninas, células-tronco animais.

\section{INTRODUCTION}

Adult tissue-specific stem cells have demonstrated the capacity to self-renew and functional rehabilitation of lost cells throughout life (Xiao et al. 2005, Viktorov et al. 2006, Viktorov et al. 2007). Nowadays, numerous diseases such as Parkinson's and Alzheimer's diseases have been treated using cell therapy, plus satisfactory results have been demonstrated (Bjugstad et al. 2008, Levy et al. 2008). Generating human neural stem cells for transplantation is now possible, either from embryonic stem cells (ES) or fetal brain tissue. Nevertheless, the current ethical debate about the usage of the excess of human embryos and fetal tissue (Sugarman 2008, Whittaker 2008) has encouraged the development of alternatives such as the appliance of adult somatic stem cells for cell therapy.

It has been reported that mammal olfactory epithelium (OE) consisted of olfactory receptor neurons, supporting cells, global and horizontal basal stem cells, which have been demonstrated to be responsible for replacing damaged cells (Chen et al. 2004, Jang et al. 2007). Therefore, OE has been considered to be an essential source for adult neural progenitor cells. In this regard, cultured cells resembling astrocytes and oligodendrocytes of mature rodent brain have been capable to produce a population of neurosphere forming cells (NSFCs) with characteristics that are similar to those seen in cells of the central nervous system (Chandran et al. 2004, Chen et al., 2004).

Dogs have been used as models for human age-related diseases and have gained wider interest as models for developing therapeutic strategies for human degenerative diseases, due to similarities in nervous system (de Lima et al. 2007, Yuasa et al. 2008).

We believe that due to the easy access of the OE neural progenitor cells, simply based in a biopsy of the cribriform plate of the ethmoid bone; these cells should be considered in cell therapies, like future application in human and veterinary medicine. Then, this experiment was to develop a protocol of stem cells extraction from canine olfactory epithelium without contaminations to be used in future pre clinical experiments.

\section{MATERIALS AND METHODS}

Primary cell culture. Twelve mongrel dogs 60 -day pregnancy age were collected of urban pound dogs from the São Paulo City. Olfactory epithelium was obtained from each dog according to previous description (Overall \& Arnold 2007). Briefly, tissue from cribriform ethmoidal lamina was collected at necropsy under sterile conditions around $1 \mathrm{~h}$ to $2 \mathrm{~h}$ postmortem. Olfactory epithelium was rinsed three times with sterile saline solution $0.9 \%$, and transferred (with minimal dissection) into a $35 \mathrm{~mm}$ Petri dish (Corning, New York, NY, USA) with $100 \mathrm{U} / \mathrm{ml}$ penicillin, $100 \mathrm{~g} / \mathrm{ml}$ streptomycin (Invitrogen, Cat. \# 15140-122). Sections were cut into pieces of about $1 \mathrm{~mm}^{3}$, and applying explants culture, the tissue was kept in culture flasks of $25 \mathrm{~cm}^{2}$ (TPP, Switzerland) at $37^{\circ} \mathrm{C}$ in DMEM/F-12 medium (Invitrogen, Cat. \#10565-018).

Cultures were maintained under standard conditions $(5 \%$ $\mathrm{CO}^{2},>37^{\circ} \mathrm{C}$ ) in DMEM/F-12 medium supplemented with $10 \%$ fetal bovine serum (FBS, HyClone, Logan, Utah, USA), and penicillin/streptomycin (1\%; PAA). The procedure was approved by the Bioethical Commission of Veterinary Medicine and Animal Science Faculty of São Paulo University.

Immunohistochemistry. Samples of OE were obtained and fixed in 10\% formalin for histological paraffin embedding. Blocks were sliced (3-4 $\mu \mathrm{m})$ and mounted onto silan-coated glass slides. PCNA (Proliferating Cell Nuclear Antigen) and Ki67 antigen levels were determined using PCNA (Santa Cruz Biotechnology, G1607) and ki67 (DAKOcytomation, M7240) monoclonal antibody with the slides stained according to the streptavidinbiotin staining procedure. Brieûy, after deparafûnization, the 
slices were heated in microwave $\left(4\right.$ times at $\left.100^{\circ} \mathrm{C}\right)$ in $0.01 \mathrm{M}$ citrate buffer solution. After gradually cooling to room temperature, the slides were incubated for 20 minutes in a $0.3 \%$ hydrogen peroxide diluted in methanol solution. Slides were rinsed with distilled water, incubated with normal rabbit serum in order to block non-speciûc binding, and incubated with primary antibody, diluted to $1: 100$ in buffer solution, overnight at $4^{\circ} \mathrm{C}$. After incubation with the secondary antibody for 30 minutes, the slides then were incubated with the avidin-biotin complex for 30 minutes. Immunostaining was visualized by diaminobenzidine (stained for 8 minutes) and counterstained with hematoxylin.

Transmission electron microscopy. For electron microscopy, we followed the descriptions of the Lima et al. (2007), briefly, samples were fixed in Karnovsky solution (5\% glutaraldehyde, $1 \%$ formaldehyde) in sodium cacodylate buffer $(0.125 \mathrm{M}$; $\mathrm{pH} 7.4)$ for $72 \mathrm{~h}$ and, dehydrated in a crescent series of ethanol and, embedded in Spurr epoxy resin (ProSciTech, Queensland). Ultrathin sections were obtained at 70-90nm on a Leica Ultracut UCT, and collected in a 200 mesh-grid. The sections were stained in uranyl acetate solution in ethanol and lead citrate, in order to be observed in a Phillips electron microscope Morgagni 268D.

Indirect Immunofluorescence. For indirect immunofluorescence, $3 \times 10^{5}$ cell/well $(1 \mathrm{ml})$ were plated in a 6 -well culture dish. The cells were grown to $60-70 \%$ confluence. Then, 24 hours after confluence, the cells were rinsed twice in phosphate-buffered saline (PBS) for 5 minutes and fixed with 4\% paraformaldehyde for 60 minutes. All cells were rinsed twice with tricine- buffered saline (TBS) for five minutes in order to eliminate any paraformaldehyde residues. Afterward, the cells were permeabilized with a $0.2 \%$ Triton X-100 in PBS. The cells were re-rinsed twice in TBS for five minutes and inespecific reactions were blocked with $3 \%$ BSA. The primary antibody incubation was carried out at 1:100 at $4^{\circ} \mathrm{C}$ over night (Table 1). FITC-conjugated anti-goat was applied for Vimentin stained at 1:100 for $1 \mathrm{~h}$ at room temperature. Similar procedure was performed using FITC-conjugated anti-mouse IgG (AP308F, Chemicon International, Temecula, CA, USA) for the other primary antibodies. The cells were rinsed twice with TBS for five minutes, followed by one wash with distillated water, mounted with Vectashield-DAPI (ABCYS, Paris, France) and examined with a LSM 510 (Carl Zeiss Microscopy, Jena, Germany).

\section{RESULTS}

Cell culture based on OE explants demonstrated rapid growth. Approximately 24 hours after plating the cells of olfactory biopsies, phase-bright spheres cells were found floating in culture flasks. In this phase, some cells were already adhering to the bottom of the culture flasks, though still surrounding the fragments (Fig.1a,b).

Culture medium was exchanged after a couple days. Clusters of the most viable cells were observed within the first week (Fig.1c). After 10 day of culture, these cells were collected from the monolayer after being rinsed twice in PBS, and dissociated in a $0.25 \%$ trypsin solution, following the seeding of $1 \times 10^{4}$ cells in a $25 \mathrm{~cm}^{2}$ flask culture (Fig. $1 \mathrm{~d}$ ). In the new flasks culture, proliferation, expansion and cellclusters formations were also observed after trypsinization (Fig.1e,f).

At the beginning, a heterogeneous population was observed, although being homogeneous, and forming colonies of fusiform cells after 20 days, which fully expanded in the culture flask after two days (Fig.2a). For this culture, the medium was changed each four days, according to the confluence of cells in the flask, and maintaining the initial characteristic of the culture (Fig.2b).

Non-specific differentiation medium was used for developing the cell culture. However, from twentieth days, stellate cells resembling neuronal cells were observed (Figure $2 \mathrm{c}, \mathrm{d}$ ). Not so far, the stellate cells were also positive for neuronal immunostaining evidenced by GFAP-positive astrocytes expression (rhodamine-red staining), and nucleus in a central position stained with DAPI nuclear staining (Fig.3a,b).

In addition, immunostaining evidenced the presence of fusiform cells expressing positive labeling of neurofilaments (FITC-conjugated antibody), a specific component of the neuronal cytoskeleton (Fig.3c). In the same way, positive expression of other specific markers to neuronal progenitor such as oligodendrocyte and III â-tubulin was also identified (Fig.3d,e).

The Ki67 immunostaining showed a trend to label cells group throughout the apical region of the OE, with diffuse labeling near the basal lamina (Fig.4a). On the other hand, PCNA immunostaining label predominantly cells groups lying above the basal lamina (Fig.4b).

The transmission electron microscopy of OE from 60day aged dogs revealed cells with electron-dense cytoplasm and same distribution as those of cell staining positive for PCNA. Metabolic activity was confirmed by presence of euchromatin in the most of cells (Fig.5).

The respiratory epithelium was characterized as ciliated pseudostratified columnar epithelium due to the arrangement of the columnar epithelial cells. These cells presented

Table 1. Primary antibody used in immunofluorescence labeling

\begin{tabular}{lcc}
\hline \multicolumn{1}{c}{ Antibody } & Laboratory & Source \\
\hline Vimentin (Type: V9, sc-6260), Dilution- 1:100. & Santa Cruz Biotechnology & Santa Cruz, California, U.S.A. \\
Oct-4 (Sc-5279)-1:100 & Santa Cruz Biotechnology & Santa Cruz, California, U.S.A. \\
Cytokeratin 18 (RGE53)- 1:100 & Santa Cruz Biotechnology & Santa Cruz, California, U.S.A. \\
III $\beta$-tubulin (TUBB3)- 1:100 & Santa Cruz Biotechnology & Santa Cruz, California, U.S.A. \\
Integrin â 1(ITGB1)- 1:100 & Santa Cruz Biotechnology & Santa Cruz, California, U.S.A. \\
Neurofilament-(ab24575): 1:100 & Abcam & Cambridge, U.S.A \\
$\beta$ Tubilin III (TUBB3)- 1:100 & Santa Cruz Biotechnology & Santa Cruz, California, U.S.A. \\
Oligodendrocyte (ab64547)- 1:100 & Abcam & Cambridge, U.S.A \\
GFAP (ab7260)- 1:100 & Abcam & Cambridge, U.S.A.
\end{tabular}

Pesq. Vet. Bras. 30(4):363-372, abril 2010 


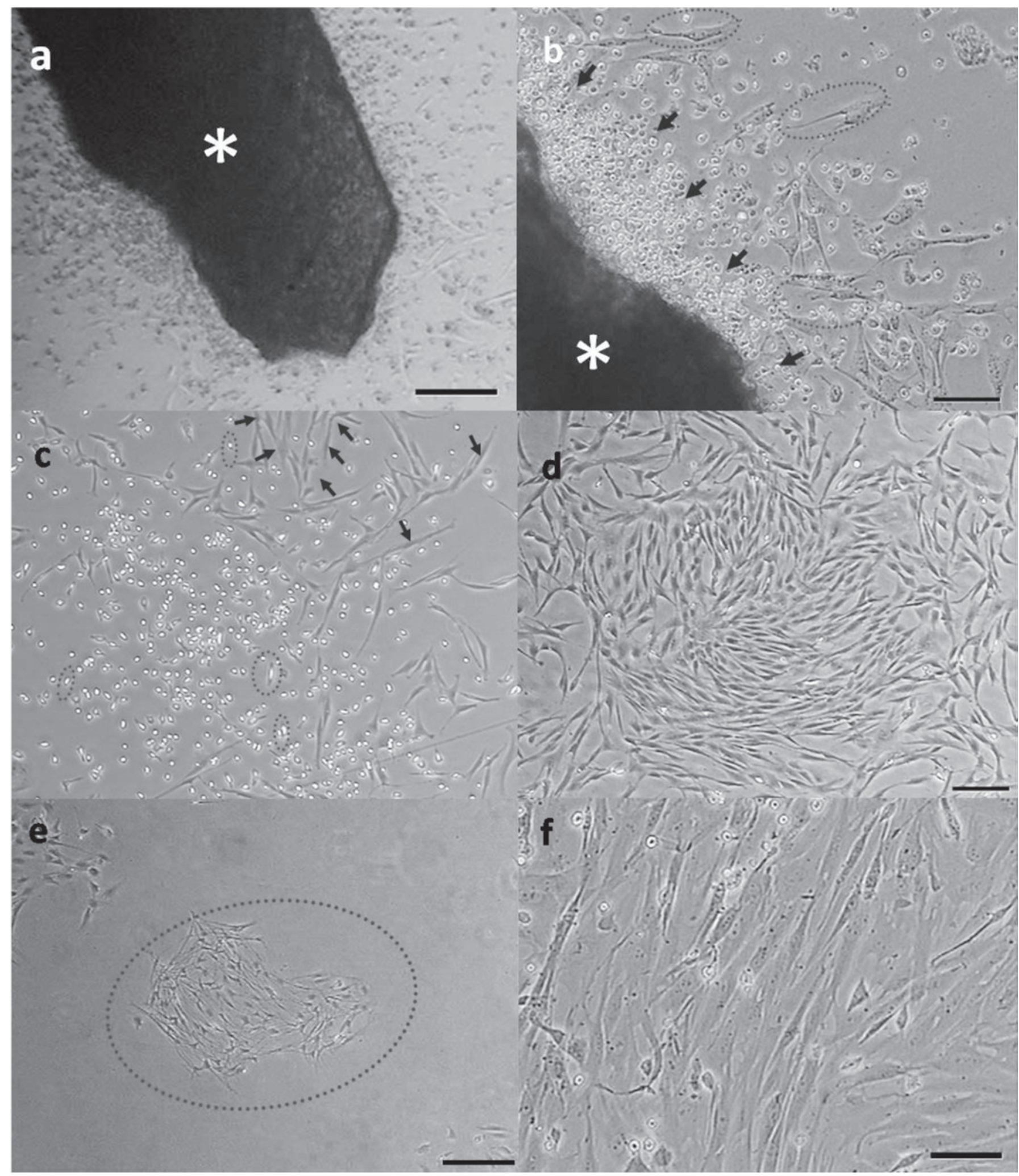

Fig.1. Olfactory epithelia of a dog at 60-day intrauterine gestation demonstrating cell detaching after $24 \mathrm{~h}$ in culture. (a) cell detaching (arrow) from the explants $\left(^{*}\right)$. (b) cells adhesions beginning close to the fragments. (c) adhered-cells in homogeneous distribution (arrows), some in division process (circle). (d) monolayer cells in total confluence before first passage. (e,f) monolayer adhered cells in the bottom of the flask in cluster formation (circles). Scale bar: (a) $50 \mathrm{~mm}$, (b) $25 \mathrm{~mm}$, (c-f) $250 \mathrm{~mm}$. 


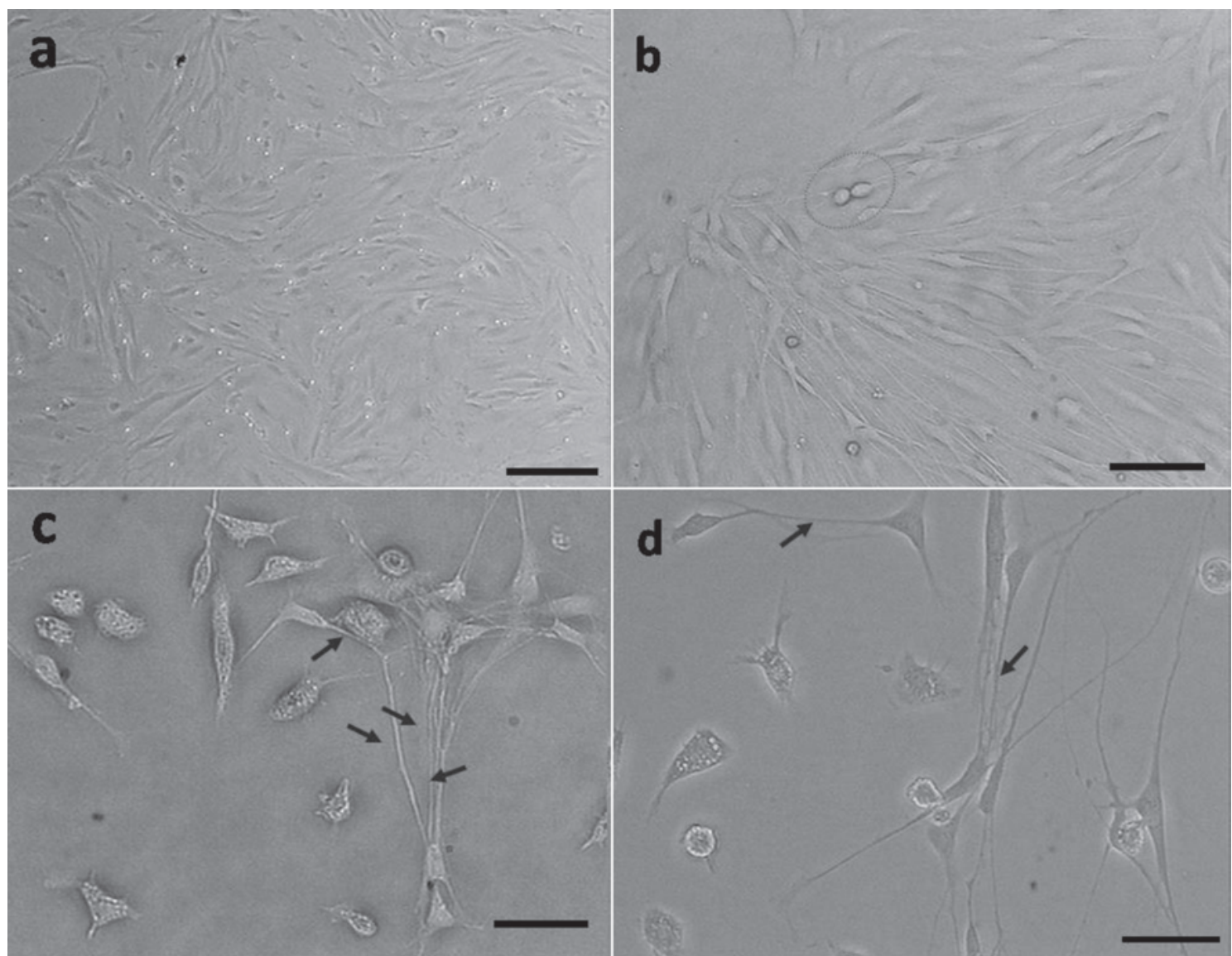

Fig.2. Olfactory epithelia of a dog at 60-day intrauterine gestation demonstrating (a,b) cell in division process, (a) brilliant points, (b) circles. (c,d) Stellate cells in cell to cell interaction, resembling neurons, through cytoplasm projections (arrows). Scale bar: (a,c,d) $25 \mathrm{~mm}$, (b) $100 \mathrm{~mm}$.

cytoplasm with intermediary electron-density when compared with basal cells. Sustentacular cells were differentiated based on the absence of cilia and lower cytoplasmatic electrondensity (Fig.6a). Olfactory neurons were visualized in close relationship with sustentacular cells. Neuronal metabolic activity was evidenced by the presence of numerous mitochondrias clustered near the nucleus (Fig.6b).

\section{DISCUSSION}

\section{Culture of olfactory epithelium from 60-day aged dogs}

Studies related to stem cells culture have been received special attention because stem cells demonstrate the capacity for renewal after trauma, also not only in basic neurogenic research, but also enabling the treatment of degenerative disease as neurological disorders, such as Parkinson's disease (Del Corral et al. 2003, Li et al. 2005, Zhang et al. 2006).

Stem cells culture from OE of experimental dog model (Krudewig et al. 2006, Overall et al. 2007) give subsidies to the establishment of protocols for obtaining progenitor cells committed with neuronal lineage of cells, avoiding to access the central nervous system.

Other author has reached promising outcomes based in dogs as an animal model used to evaluate diseases that can be find in human (Alves et al. 2009, Grando et al. 2009) or to obtain progenitor cells that can be applied in different types of cell therapy. In this way, Kerkis et al. (2008) transplanted a population of Human immature Dental Pulp Stem Cell into 4 littermate Golden Retriever Dogs affected by Muscular Dystrophy (GRMD), when these authors verified presence of significant engraftment in GRMD dog muscles with failure in the expression of dystrophin. These results support our data about the potential of dogs as an animal model in stem cell researches, and encourage the establishment of the canine model to compare with disease such as those seen in humans. Using this canine $x$-linked muscular dystrophy model, recent data presented controversies related to the real phenotypes variability presented by these dogs (Ambrósio et al. 2008, Ambrósio et al. 2009, Barthélémy et al. 2009) then pre-clinical results must be interpreted with care and attention.

Dog's OE explants maintained in culture in D-MEM/F12 for 60-day, demonstrated high rate of releasing cells in culture after 24 hours. Recent studies have demonstrated a remarkable functional plasticity in multilineage embryonic stem cells revealing high potential of differentiation, as well as an elevated mitogenesis (Lumelsky et al. 2001, Odorico et al. 2001). According to Pagano et al. (2000), this effect 


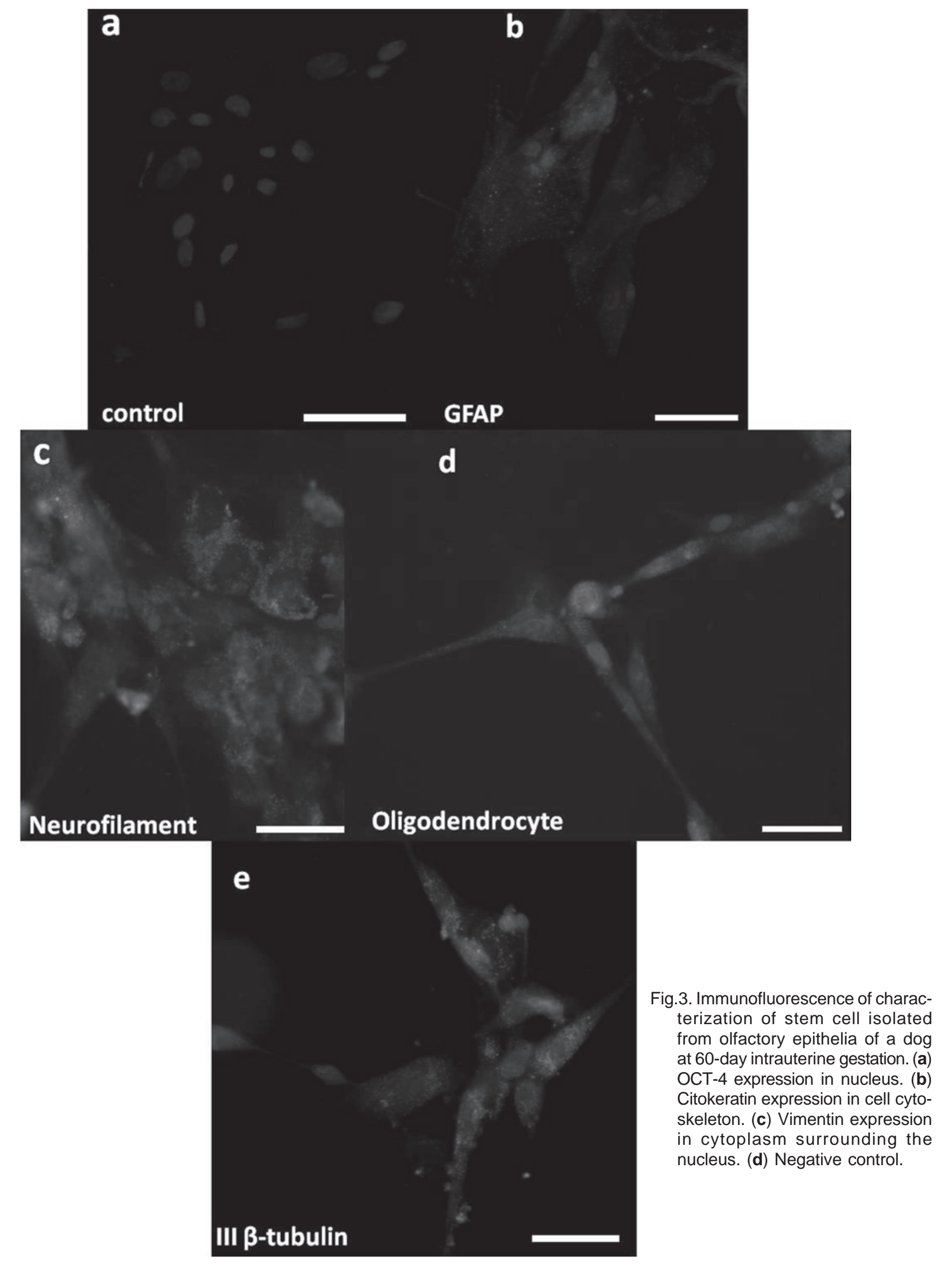




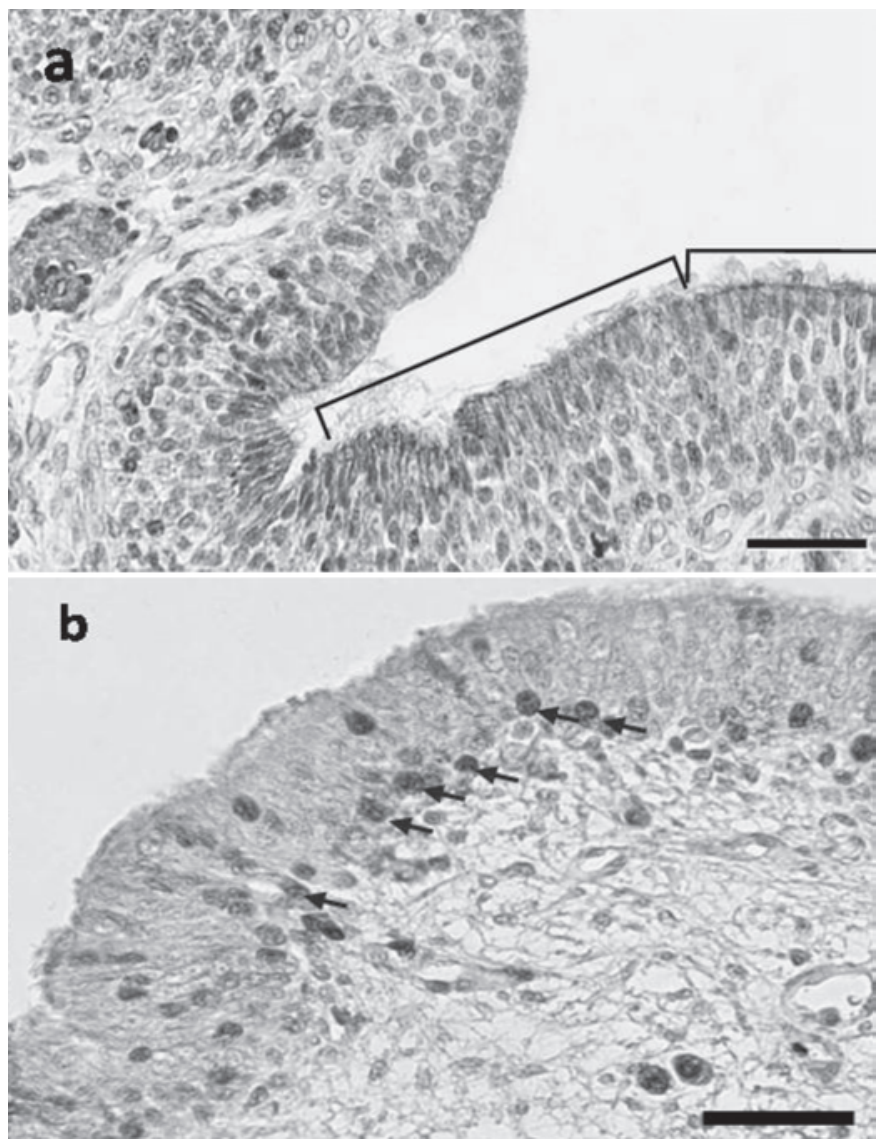

Fig.4. Olfactory epithelia of a dog at 60-day intrauterine gestation. (a) Ki67 (detached area). (b) PCNA (blue arrows). Scale bar: $40 \mathrm{~mm}$.

is related to its capacity of self-renewal and its unlimited potential for differentiation, when compared to adult cells. In their studies, stem cells isolated from the olfactory bulb and submitted to mitogenic growing factors constituted only one percent of true stem cells. The remaining cells were composed of the transient population, which eventually died or underwent differentiation.

Cells with high potential to confluence were observed attached to the flask at $5^{\text {th }}$ day in culture. Similar observations were made by Murrell et al. (2005), when they established viable cells from 7 to 10 days in culture. In agreement, Krudewig et al. (2006) achieved total adhesion and confluence of cells isolated originated from olfactory bulb of dogs following 3 days in medium supplemented with forskoline and FGF-2. Particularly, in our culture, the complete confluence was only reached after 10 days.

After 20 days in culture, cells from OE were observed demonstrating fusiform morphology and maintaining high level of homogeneity. This characteristic was also reported by Pagano et al. (2000), Jin et al. (2002) and Zhang et al. $(2005,2006)$, when it was promoted differentiation of cells into the neuronal lineage through factor of neurogenic stimulation (EGF, FGF-2, and BDNF-brain-derived neurotrophic factor).

The fourth passage was characterized by the presence of stellate cells, evidencing cytoplasmic expansions which resemble the interaction observed among neuronal cells. This aspect was described by Roisen et al. (2001) during the eighteenth passage. Other authors as Krudewig et al. (2006), achieved same results in culture, among the sixth and ninth passages, and confirmed by immunostaining for GFAP and Fibronectin. However, the best results were obtained by Zhang et al. (2006), after treatment with RA1FNSShh and VAChT (Vesicular acetylcholine transporter), revealing neuritis formation and synaptic vesicles.

In our study, stem cells collected from OE of young dogs provided the opportunity of its future application in cell therapies. We detach that the cell culture protocol was based only in the isolation and expansion of cells without further differentiation induced-program. In addition, cell-to-cell

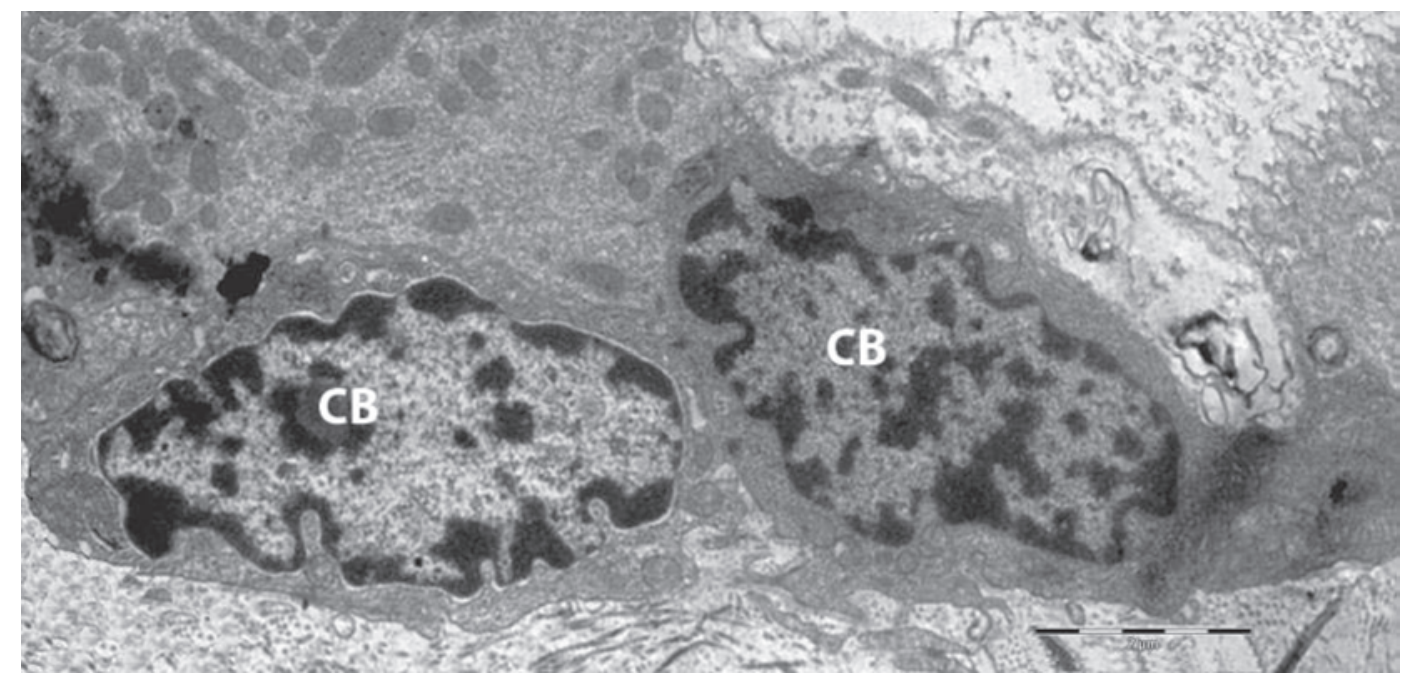

Fig.5. Electronmicrograph of olfactory epithelia of a dog at 60-day intrauterine gestation demonstrating the morphology of cell above the proper lamina, which orientation resembles the cells stained with PCNA. CB: basal cells. Scale bar: $2 \mathrm{~mm}$. 

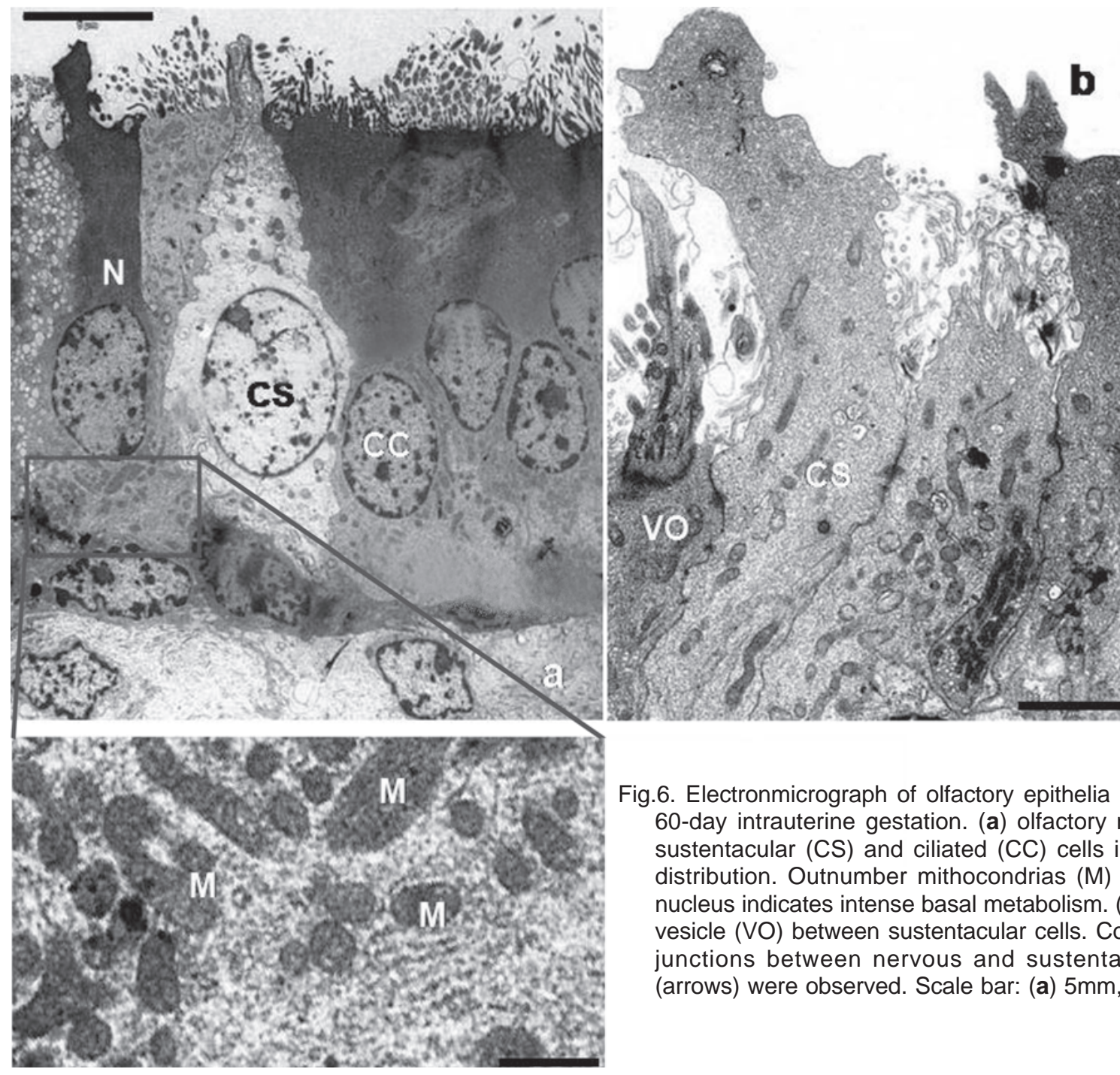

Fig.6. Electronmicrograph of olfactory epithelia of a dog at 60-day intrauterine gestation. (a) olfactory neuron $(\mathrm{N})$, sustentacular (CS) and ciliated (CC) cells in columnar distribution. Outnumber mithocondrias (M) around the nucleus indicates intense basal metabolism. (b) olfactory vesicle (VO) between sustentacular cells. Communicant junctions between nervous and sustentacular cells (arrows) were observed. Scale bar: (a) $5 \mathrm{~mm}$, (b) $2 \mathrm{~mm}$.

interactions through cytoplasmatic projections and the tendency to form colonies supported the hypothesis of the potentiality of these cells to source neuronal lineages. A similar aspect was also observed by Calof et al. (2002) and Chandran et al. (2004) for GFAP- positive expression differentiated cells from human sub-ventricular zone and olfactory bulb.

The predominance of potential for growth and expansion in culture of cells from young dogs compared to adults produce cells whose morphology is similar to those reported in the literature as neuronal lineages.

\section{PCNA and Ki67 immunostaining of cells from OE of 60-day aged}

Immunostaining for proliferating cell nuclear antigen (PCNA) and Ki67 of the olfactory epithelium allowed to identify the most phases of the cell cycle as was described by Tsuji et al. (1992) and Pendleton et al. (1993) studying expression of protein markers in human.

High tendency for Ki67 expression was observed predominantly in the apical layer, when compared to PCNA immunostaining protocol whose showed positive labeling essentially above the basal layer, according to Aguiar (1996), Costa (1997), Bruck et al. (2001) in humans, and Alves et al. (2007) in dogs. Thus, although the Ki67 label most number of phases, all phases except $G_{0}$ (Capello et al. 2006), when compared with PCNA, it was able to identify allowed only measure the longest stages of this process (Jascur \& Boland 2006), justifying the intensity of Ki67 labeling index present on the apical cells of $\mathrm{OE}$, whose the division process occur more slowly.

The pseudostratified pattern of the OE from 60-day aged dog allowed labeling positive nuclear cells in different layer. This observation was supported by hypothesis that populations of stem cells are resident in middle and basal layer of the OE, as was described by Higuchi et al. (2005) studying dynamic of precursor of the OE in young Cavia sp. Similarly, Ohta et al. (2000) and Legrier et al. (2001) reached same results studying the cell cycle proliferation using PCNA technique as well as the presence of epidermal growth factor (EGFR) and neurogenic regulation in mices. 
The ultrastructural analysis demonstrated morpholo-gical similarity between basal cells and those present in the middle layer and sustentacular epithelium as was described by Caggiano et al. (1994) and Huard et al. (1998). In addition, according to Nakamura et al. (1998) and Higuchi et al. (2005), sustentacular cells and olfactory neurons could be characterized by the presence of communicant gap junctions. Besides, numerous mitochondrias disperse evenly in the cytoplasm of neurons, as well as chromatin and euchromatin in the cytoplasm of basal cells.

\section{CONCLUSION}

These aspects give subsidies to support the hypothesis about resident progenitor cells among the basal cells of the OE, committed to generate all the constituents of this region, particularly sensorial neurons.

Acknowledgements.- To FAPESP (Fundação de Amparo à Pesquisa do Estado de São Paulo (Process Number 05/57787-6) and INCTC (Instituto Nacional de Ciências e Tecnologia em Céluas-tronco e Terapia Celular) for financial support.

\section{REFERENCES}

Aguiar M.C.F. 1996. Estudo comparativo das proteínas p53, PCNA, Ki67 e das regiões organizadoras nucleorares (NORs) no epitélio de revestimento da mucosa próximo ao carcinoma epidermóide de boca. São Paulo. Tese de Doutorado em Patologia Bucal, Faculdade de Odontologia, USP, São Paulo, SP. 110p.

Alves F.R., Feitosa M.L.T., Gatti A., Fadel L., Unruh S.M., Ambrósio C.E., Sterman F.A., Pinto A.C.B.C.F. \& Miglino M.A. 2009. Radiologic images of the thoracic cavity of Golden Retriever dogs affected by muscular dystrophy. Pesq. Vet. Bras. 29:99-104.

Alves F.R., Santos T.C., Freiberger S., Ambrósio C.E. \& Miglino M.A. 2007. The dynamic of precursor of the olfactory epithelium of mongrel dogs: An immunohistochemical and ultrastructural study. Pesq. Vet. Bras. 27:388-392.

Ambrósio C.E., Fadel L., Gaiad T.P., Martins D.S., Araújo K.P., Zucconi E., Brolio M.P., Giglio R.F., Morini A.C., Jazedje T., Froes T.R., Feitosa M.L., Valadares M.C., Beltrão-Braga P.C., Meirelles F.V. \& Miglino M.A. 2009. Identification of three distinguishable phenotypes in golden retriever muscular dystrophy. Genet. Mol. Res. 8(2):389-396.

Ambrósio C.E., Valadares M.C., Zucconi E., Cabral R., Pearson P.L., Gaiad T.P., Canovas M., Vainzof M., Miglino M.A., Zatz M. 2008. Ringo, a Golden Retriever Muscular Dystrophy (GRMD) dog with absent dystrophin but normal strength. Neuromuscul Disord. 18:892893.

Barthélémy I., Barrey E., Thibaud J.L., Uriarte A., Voit T., Blot S. \& Hogrel J.Y. 2009. Gait analysis using accelerometry in dystrophin-deficient dogs. Neuromuscul. Disord. 11:788-796.

Bjugstad K.B., Teng Y.D. Jr, Redmond D.E., Elsworth J.D., Roth R.H., Cornelius S.K., Snyder E.Y \& Sladek Jr J.R. 2008. Human neural stem cells migrate along the nigrostriatal pathway in a primate model of Parkinson's disease. Exp. Neurol. 211:362-369.

Bruck I., O'Donnel M. 2001. The ring-type polymerase clamp family. Genome Biol. 2:3001-3003.

Caggiano M., Kauer J.S. \& Hunter D.D. 1994. Global basal cells are a neuronal progenitors in the olfactory epithelium: A lineage analysis using a replication-incompetent retrovirus. Neuron. 13:339-352.

Calof A.L., Bonnin A., Crocker C., Kawauchi S., Murray R.C., Shou J. \& Wu H.H. 2002. Progenitor cells of the olfactory receptor neuron lineage. Microsc. Res. Tech. 58:176-188.
Cappello F., Ribbene A., Campanella C., Czarnecka A.M., Anzalone R., Bucchieri F., Palma A. \& Zummo G. 2006. The value of immunohistochemical research on PCNA, p53 and heat shock proteins in prostate cancer management: A review. Eur. J. Histochem. 50:25-34.

Chandran S., Compston A., Jauniaux E., Gilson J., Blakemore W. \& Svendsen C. 2004. Differential generation of oligodendrocytes from human and rodent embryonic spinal cord neural precursors. Glia 47:314-324.

Chen X.Y., Fang H.S. \& Schwob J.E. 2004. Multipotency of purified, transplanted globose basal cells in olfactory epithelium. J. Comp. Neurol. 469:457-474.

Costa A.L.L. 1997. Dupla marcação PCNA/AgNOR e Ki-67/ AgNOR em carcinoma epidermóide de boca. São Paulo. Tese de Doutorado em Patologia Bucal, Faculdade de Odontologia, USP, São Paulo, SP. 84p.

Del Corral R.D., Olivera-Martinez I., Goriely A., Gale E., Maden M. \& Storey K. 2003. Opposing FGF and retinoid pathways control ventral neural pattern, neuronal differentiation, and segmentation during body axis extension. Neuron 40:65-79.

Grando A.P., Mariana A.N.B., Miglino M.A., Sterman F.A., Zatz M., Nakayama L.M., Feitosa M.L., Martins D.S., Morini A.C., Santos J.P.A., Fadel L., Alves F.R. \& Ambrósio C.E. 2009. Abdominal and pelvic ultrasonography in healthy golden retriever dogs, carriers and affected by gradual muscular dystrophy. Ciência Rural 29:123-128.

Higuchi Y., Nakamura H., Kawasaki M. \& Takahashi S. 2005. The dynamics of precursor cells in the olfactory epithelium of juvenile and adult guinea pigs. Eur. Arch. Otorhinolaryngol. 262:64-68.

Huard J.M.T., Youngentob S.L., Goldstein B.J., Luskin M.B. \& Schwob J.E. 1998. Adult olfactory epithelium contains multipotent progenitors that give rise to neurons and non-neural cells. J. Comp. Neurol. 400:469-486.

Jang W.C., Kim K.P. \& Schwob J.E. 2007. Nonintegrin laminin receptor precursor protein is expressed on olfactory stem and progenitor cells. J. Comp. Neurol. 502:367-381.

Jascur T. \& Boland C.R. 2006. Structure and function of the components of the human DNA mismatch repair system. Int. J. Cancer. 119:20302035.

Jin K., Mao X.O., Sun Y., Xie L. \& Greenberg D.A. 2002. Stem cell factor stimulates neurogenesis in vitro and in vivo. J. Clin. Invest. 110:311319.

Kerkis I., Ambrósio C.E., Kerkis A., Martins D.S., Zucconi E., Fonseca S.A.S., Cabral R.M., Maranduba C.M.C., Gaiad T.P., Morini A.C., Vieira N.M., Brolio M., Sant'Anna O.A., Miglino M.A. \& Zatz M. 2008. Early transplantation of human immature dental pulp stem cells from baby teeth to golden retriever muscular dystrophy (GRMD) dogs: Local or systemic? J. Trans. Med. 6:35.

Krudewig C., Deschl U. \& Wewetzer K. 2006. Purification and in vitro characterization of adult canine olfactory ensheathing cells. Cell and Tissue Res. 326:687-696.

Legrier M.E., Ducray A., Propper A., Chao M. \& Kastner A. 2001. Cell cycle regulation during mouse olfactory neurogenesis. Cell Growth and Differentiation 12:591-601.

Levy Y.S., Bahat-Stroomza M., Barzilay R., Burshtein A., Bulvik S., Barhum Y., Panet H., Melamed E. \& Offen D. 2008. Regenerative effect of neuralinduced human mesenchymal stromal cells in rat models of Parkinson's disease. Cytotherapy 10:340-352.

Li Y., Field P.M. \& Raisman G. 2005. Olfactory ensheathing cells and olfactory nerve fibroblasts maintain continuous open channels for regrowth of olfactory nerve fibres. Glia 52:245-251.

Lima A.R., Nyengaard J.R., Jorge A.A.L., Balieiro J.C.C., Peixoto C., Fioretto E.T., Ambrósio C.E., Miglino M.A., Zatz M. \& Ribeiro A.A.C.M. 2007. Muscular dystrophy-related quantitative and chemical changes in adenohypophysis GH-cells in golden retrievers. Growth Hormone Igf Res. 17:480-491. 
Lumelsky N., Blondel O., Laeng P., Velasco I., Ravin R. \& McKay R. 2001. Differentiation of embryonic stem cells to insulin-secreting structures similar to pancreatic islet. Science 293:428-428.

Murrell W., Feron F., Wetzig A., Cameron N., Splatt K., Bellette B., Bianco J., Perry C., Lee G. \& Mackay-Sim A. 2005. Multipotent stem cells from adult olfactory mucosa. Develop. Dynamics 233: 496-515.

Nakamura H., Fujiwara M., Kawasaki M., Nonomura N. \& Takahashi S. 1998. Age-related changes in dividing cells of the olfactory epithelium of the maturing guinea pig. Eur. Arch. Oto-Rhin-Laryngol. 255:289292.

Odorico J.S. \& Kaufman D.S. 2001. Thomson JA. Multilineage differentiation from human embryonic stem cell lines. Stem Cells 19:193-204.

Ohta Y. \& Ichimura K. 2000. Immunohistochemical localization of proliferating cells and epidermal growth factor receptors in mouse olfactory epithelium. ORL J. for Oto-Rhino-Laryngology and its Related Specialties 62:20-25.

Overall K.L. \& Arnold S.E. 2007. Olfactory neuron biopsies in dogs: A feasibility pilot study. Appl. Anim Behav. Sci. 105:351-357.

Pagano S.F., Impagnatiello F., Girellia M., Cova L., Grioni E., Onofri M., Cavallaro M., Etteri S., Vitello F., Giombini S., Solero C.L. \& Parati E.A. 2000. Isolation and characterization of neural stem cells from the adult human olfactory bulb. Stem Cells 18:295-300.

Pendleton N., Dixon G.R., Burnett H.E., Occleston N.L., Myskow M.W. \& Green A. 1993. Expression of proliferating cell nuclear antigen (PCNA) in dysplasia of the bronchial epithelium. J. Pathol. 170:169-172.

Roisen F.J., Klueber K.M., Lu C.L., Hatcher L.M., Dozier A., Shields C.B. \& Maguire S. 2001. Adult human olfactory stem cells. Brain Res. 890:11-22.
Sugarman J. 2008. Human stem cell ethics: Beyond the embryo. Cell Stem Cell 2:529-533.

Tsuji T., Sasaki K., Kimura Y., Yamada K., Mori M. \& Shinozaki F. 1992. Measurement of proliferating cell nuclear antigen (PCNA) and its clinical-application in oral cancers. Int. J. Oral Maxillofac. Surg. 21:369372.

Viktorov I.V. Savchenko E.A., Ukhova O.V. \& Yu N. 2006. Alekseyeva and V. P. Chekhonin. Multipotent stem and progenitor cells of the olfactory epithelium. Bull. Exp. Biol. Med. 142:495-502.

Viktorov I.V., Savchenko E.A. \& Chekhonin V.P. 2007. Spontaneous neural differentiation of stem cells in culture of human olfactory epithelium. Bull. Exp. Biol. Med. 144:596-601.

Whittaker P. 2008. Human stem cells and their storage: Some ethical issues. Cryoletters 29:157-164.

Xiao M., Klueber K.M., Lu C., Guo Z., Marshall C.T., Wang H. \& Roisen F.J. 2005. Human adult olfactory neural progenitors rescue axotomized rodent rubrospinal neurons and promote functional recovery. Exp. Neurol. 194:12-30.

Yuasa K., Nakamura A., Hijikata T. \& Takeda S. 2008. Dystrophin deficiency in canine $\mathrm{X}$-linked muscular dystrophy in Japan (CXMDJ) alters myosin heavy chain expression profiles in the diaphragm more markedly than in the tibialis cranialis muscle. BMC Musculoskeletal Disorders 9:1-12.

Zhang X.D. \& Cai J. 2005. Induction of oligodendrocytes from adult human olfactory epithelial-derived progenitors by transcription factors. Stem Cells 23:442-453.

Zhang X.D., Klueber K.M., Guo Z., Cai J., Lu C., Winstead W.I., Qiu M. \& Roisen F.J. 2006. Induction of neuronal differentiation of adult human olfactory neuroepithelial-derived progenitors. Brain Res. 1073:109-119. 